\title{
Top incomes, wealth and inheritance: special issue in homage to Tony Atkinson
}

\author{
Facundo Alvaredo $^{1,2}$ • Cecilia García-Peñalosa ${ }^{3}$
}

Published online: 29 May 2018

(C) Springer Science+Business Media, LLC, part of Springer Nature 2018

\section{Editorial introduction}

In the second of the three issues that the Journal of Economic Inequality is publishing in honour of Sir Anthony Barnes "Tony" Atkinson, we turn to what has become one of the most dynamic areas of research in recent years, the evolution of top incomes and the concentration of wealth. Tony's contributions were path-breaking in the field of inequality studies, where he pioneered at a time in which the profession was paying little attention to applied distributional issues. His 1978 book with Alan Harrison, Distribution of Personal Wealth in Britain, is probably the finest example of his approach: it combines the data collection, the critical and cautious production of series, the historical perspective, and the theoretical analysis. The book, spanning data from the 1910 s to the 1970 s, documented a massive reduction in wealth inequality over three generations. Falling wealth and income inequality subsequently led, to some extent, to complacency about the distributional implications of economic prosperity, but alarm bells started ringing in the 1990s when Tony and other authors "brought income distribution in from the cold" (Atkinson 1997). In this context of renewed interest in the dynamics of distributional variables, Tony became a driving force in the efforts to understand what has been happening at the top of the distribution.

A succession of studies has constructed top income share series for a large number of countries (starting with Piketty (2001) for France, Piketty and Saez (2003) for the US, Atkinson (2005) for the UK, and the two multi-country volumes edited by Atkinson and

Facundo Alvaredo

alvaredo@gmail.com

Cecilia García-Peñalosa

cecilia.garcia-penalosa@univ-amu.fr

1 Paris School of Economics, Paris, France

2 IIEP-UBA-Conicet, Buenos Aires, Argentina

3 CNRS, EHESS, Centrale Marseille, AMSE and CESifo, Aix-Marseille University, Marseille, France 
Piketty 2007 and 2010). ${ }^{1}$ The World Top Incomes Database (WTID) was created in January 2011 with the aim of providing convenient and free access to all the existing series, which, by that time, had expanded to include more than thirty countries, thanks to the contribution of over fifty researchers. Tony was one of the leaders of this venture, played a key role in assuring the formation of the network of researchers, and acted as co-director together with Facundo Alvaredo, Thomas Piketty and Emmanuel Saez. He was also the most regular and active contributor. Each year, a few hours after the publication of the necessary income tax tabulations by HMRC, he would send the updates to the UK top income share series for publication in the database. Not only that: he got progressively involved in producing the historical series for twenty countries!

Despite researchers' best efforts, the units of observation, the income concepts, and also the interpolation techniques were never made fully homogeneous over time and across countries. These shortcomings highlighted the need for a methodological re-examination. For these reasons, in 2015 the WTID was subsumed into WID.world, the World Wealth and Income Database (now relabelled the World Inequality Database). In addition to the top income share series, reporting the share of income going to the top decile of the population, WID.world includes series for Distributional National Accounts (DINA, see Alvaredo et al. (2016)), aggregate wealth-income ratios, as well as series for the distribution of wealth for an increasing number of countries (including the most recent revision and extension of the UK wealth distribution series from Alvaredo et al. (2018)).

One of the implications of the literature on top incomes has been the growing recognition that, in seeking explanations for rising income inequality, we need to look not only at earnings, but also at income from capital. Interest, dividends, and rents represent a fraction of total personal income, but they are nonetheless significant, especially at the top. Linked to the increase in capital income concentration and the inequality of saving rates, the ratio of total personal wealth to total personal income has also been rising. One consequence is that the role of inherited wealth in the process of accumulation - which declined for much of the twentieth century - has, in a number of countries, begun to regain greater significance. In the first article in this issue, Wealth and Inheritance in Britain from 1896 to the Present, Tony provides historical evidence on the importance of inheritance in the UK before the First World War, when total transmitted wealth represented some 20 per cent of net national income, falling to below 5 per cent in the late 1970s. Since then, there has been an upturn: a rise from 4.8 per cent in 1977 to 8.2 per cent in $2006 .{ }^{2}$ Tony stresses that "the rise relative to national income is what matters for the taxable capacity. At a marginal tax rate of a third, a rise of 3 percentage points would add 1 percentage point of national income to potential tax revenue, making a significant contribution to reducing the deficit." He also stresses that when a person passed on shares to their children, the underlying value of these shares was in the past greater than the stock market valuation. "Seen in this light, part of the fall in bequests in the early 1970s may have been due to falling stock prices, with their counterpart in rising net worth of the corporate sector. To this extent, the answer may be, not that inheritance has returned, but that it never really went away."

The literature on top incomes has provided renewed evidence that household surveys tend to underestimate incomes at the top of the distribution. From a theoretical perspective, this does not necessarily imply that surveys underestimate inequality levels in all cases, but in countries where both register and survey data are available, the former generally

\footnotetext{
${ }^{1}$ For surveys of this literature, see also Atkinson et al. (2011) and Alvaredo et al. (2013).

${ }^{2}$ See also Piketty (2011) for evidence on France.
} 
exhibits higher concentration. Furthermore, there are notable gaps between (mainly property) incomes in surveys and national accounts; this translates into discrepancies in the growth rates displayed in both sources (Bourguignon 2015; Deaton 2005; Ravallion 2003). Given the differences in treatment and definitions, it is not evident how to relate national accounts to income in surveys, but in developing countries the gaps can be substantial, calling for an assessment of the effect of the missing income on survey-based inequality. In Simple adjustments on observed distributions for missing income and missing people, François Bourguignon explores how information on missing income and missing people in surveys (as compared to national accounts) can be used to perform corrections of distributional data. Starting from a decomposition property of the Gini coefficient discussed in Atkinson and Bourguignon (2000) and Atkinson (2007), the article in this issue extends the analysis by providing alternative adjustment methods. The attractiveness of the approach is that it uses three simple parameters to perform the correction: how much income and how many people are missing, as well as which range of income should bear the correction. The discussion provided in the paper implies that care should be taken when comparing distributions, whether over time or across countries, as changes in missing income may imply that the bias resulting from using household surveys changes over time.

We have already discussed the necessity of looking not only at earnings but also at capital income. A related piece of the puzzle refers to their joint distribution, a topic that has received limited explicit consideration in the literature. It is important to know whether the same people are at the top of both the distribution of capital income and that of earned income. In the nineteenth century, the correlation was negative: capitalists were at the top of one distribution and at the bottom of the other. A number of contributions have shown that capital owners and the 'working rich' (high-pay executives and financial-sector employees) now appear to co-habit the top. ${ }^{3}$ Has a negative correlation in the nineteenth century been replaced by a zero or positive correlation today? To understand the changing relationship between earned and capital incomes, we need to consider the mechanisms that link the two sources. At one extreme, there is the accumulation of wealth out of earned income; at the other, there is the effect of family wealth (and the resulting social connections) on earnings.

To address these questions, Rolf Aaberge, Tony, and Sebastian Königs introduce, in From classes to copulas: wages, capital and top incomes, the copula function as a tool for exploring the changing association between earnings and capital income. The copula function can be used to examine whether there is a positive association, a negative one or independence between the two sources. The authors then illustrate this approach using tax records from Norway. Scandinavian countries are interesting in this respect as tax reforms affecting the treatment of capital income have often been argued to have been a source of growing inequality. Their analysis shows that in the decade starting in 1995 the association between earned and capital incomes grew stronger for those in the top 50 per cent of the income distribution, but became weaker for those in the top 1 per cent. These results imply, again, that the behaviour of income can vary considerably at different points of the distribution.

Three empirical contributions in this issue illustrate the range of questions and recent developments that have been raised by the literature on top incomes: an application of new methods for the production of inequality series, which we find in the article focusing on Russia based on the Distributional National Accounts approach; an analysis of gender

\footnotetext{
${ }^{3}$ See Atkinson et al. (2011), Alvaredo et al. (2013), and Wolff and Zacharias (2009).
} 
inequality and the glass ceiling based on tax records; and a study on the impact of banking crisis on top income shares.

As mentioned above, several reasons implied that the original top income share series in WTID were not fully comparable across countries, and were not fully consistent with the national accounts. A renovated approach to the measurement of economic inequality consistent with macro aggregates should rebuild the bridges between distributional data available from micro-data sources and national accounts aggregates. This is not an easy task. The DINA-Distributional National Accounts approach builds on the top income literature and goes a step further by attempting to produce distributional statistics that are comparable across countries (Alvaredo et al. 2016). The aim is to provide annual estimates of the distribution of income and wealth using concepts that are consistent with the macroeconomic national accounts. In this way, the analysis of growth and inequality can be carried over in a coherent framework. The article by Filip Novokmet, Thomas Piketty and Gabriel Zucman, From Soviets to Oligarchs: Inequality and Property in Russia 1905-2016, applies the DINA approach to provide series on the accumulation and distribution of income and wealth from the Soviet period until the present day through the combination of national accounts, survey, and wealth and fiscal data (including recently released tax information on high-income taxpayers). The results indicate that official survey-based measures vastly underestimate the rise of inequality since 1990, and that top income shares are now similar to those observed in the United States. The article also shows that inequality has increased substantially more in Russia than in China and other ex-communist countries in Eastern Europe; the authors argue that this is the result of the particular features of the transition strategy followed in Russia.

There exists a vast literature on gender inequality in earnings that since the 1960s has been explaining the different labour market performances of women and men. A separate body of work has focused on women's access to top jobs, and coined the term 'glass ceiling' to express the difficulty that women experience in accessing high-rank positions. Somewhat surprisingly, the implications of the glass ceiling for gender gaps in top incomes have received little attention. Once again, Tony proved to be a pioneer, and wrote, together with Alessandra Casarico and Sarah Voitchovsky (in cooperation with Facundo Alvaredo, Jørgen Modalsli, and Jakob Søgaard), one of the first papers on this topic, Top incomes and the gender divide. The article in this issue uses tax data from eight countries to examine income gaps and differences in the presence of men and women at the top of the distribution. As expected, women are under-represented at the top, in line with evidence on average earnings and top jobs' shares. The article confirms one of the main conclusions of the literature on earnings, which finds that during the past decades there has been substantial convergence, but that it has been greater at the bottom than at the top of the earnings distributions. Similarly, the presence of women at the top increased over time, although the rise has been smaller the higher we climb the income ladder. The most significant contribution is, however, the finding that there are marked differences by gender when income is decomposed between its three sources (earnings, self-employment income and capital income). Notably, for women at the top, capital income represents a larger share of their income compared to men, and this is so in the eight countries examined. Although capital income seems to have been historically essential to allow women to enter the top-income groups, its role has been falling over time, indicating that, with some delay, women at the high-end of the distribution have followed the overall pattern of moving from capitalists to working-rich.

The availability of data on top incomes has sparked interest in what determines the shares of those at the top of the distribution. Salvatore Morelli, in Banking crises in the US: the response of top income shares in historical perspective, contributes to this literature by 
examining the response of the share of top income households in the US to the occurrence of banking crises. The article is embedded in the macroeconomics tradition, both in terms of linking distributional dynamics to macro factors and in its methodology. Morelli models both the shape of the upper tail of the income distribution and top income shares through an autoregressive distributed lags model in which distributional variables depend on their own past values and on external 'impulses' (in this case, the occurrence of a banking crisis). The main advantage of this approach is that, since it includes various lags of the impulse variable, it presents a flexible formulation that allows the impact of banking crises to either take time to affect income shares or to have a strong initial impact that then die down. Using data since the beginning of the twentieth century, the author finds that banking crises tend to reduce the income share of the top decile. This effect encompasses heterogeneous responses, with the bottom half of the top decile experiencing an increase in their share, and those at the top half of the decile a reduction. Moreover, the effects seem to be small in magnitude and short-lived, with the impact lasting only 5 years. The author interprets this result as providing support to the hypothesis that short-run macroeconomic factors do not result in significant and permanent changes in inequality, and that only institutional changes and policies can do so.

Tony's contributions to the study of wealth and income inequality were path breaking. This issue reflects his intellectual stimulus as well as the sense of community that Tony built around him. Three of the articles were written or co-written by Tony, whilst the other three are based on long-standing research questions that he discussed with the authors, or related to more recent conversations with them. Tony's work has taught us how a meticulous and sober treatment of data should be used to lead to sharp conclusions and innovative policy action. In this respect, one dimension of his legacy reminds us that any source is open to challenge, and that we should always be aware of the underlying hypotheses, and explicit about what we are and are not able to measure. Another dimension of his legacy calls for a clear recognition of the complexity of distributional phenomena, and for building bridges across disciplines. Tony's restless curiosity is, we hope, well represented in this collection of works.

\section{References}

Alvaredo, F., Atkinson, A.B., Morelli, S.: Top wealth shares in the UK over more than a century Forthcoming. J Public Econ. (2018)

Alvaredo, F., Atkinson, A.B., Piketty, T., Saez, E.: The top $1 \%$ in international and historical perspective. J Econ. Perspect. 27, 1-21 (2013)

Alvaredo, F., Atkinson, A.B., Chancel, L., Piketty, T., Saez, E., Zucman, G.: Distributional National Accounts (DINA) guidelines: concepts and methods used in WID.world, WID.world Working Paper 2016/2 (2016)

Atkinson, A.B.: Top incomes in the UK over the 20th Century. J Royal Stat. Soc.: Ser. A (Statistics in Society) 168(2), 325-343 (2005)

Atkinson, A.B., Bourguignon, F.: Introduction: Income distribution and Economics. In: Atkinson, A.B., Bourguignon, F. (eds.) Handbook of Income Distribution, volume 1, North Holland. Elsevier, Amsterdam (2000)

Atkinson, A.B.: Measuring top incomes: methodological issues. In A.B. Atkinson and T. Piketty, op. cit., ch. 2 (2007)

Atkinson, A.B.: Bringing income distribution in from the cold. Econ. J. 107, 297-321 (1997)

Atkinson, A.B., Piketty, T., Saez, E.: Top incomes in the long run of history. J. Econ. Lit. 49, 3-71 (2011)

Atkinson, A.B., Piketty, T.: Top incomes over the twentieth century: a contrast between continental European and English-speaking countries. OUP, Oxford (2007)

Atkinson, A.B., Piketty, T.: Top Incomes: A Global Perspective. Oxford University Press, Oxford (2010) 
Atkinson, A.B., Harrison, A.: Distribution of Personal Wealth in Britain. Cambridge University Press, Cambridge (1978)

Bourguignon, F.: Appraising income inequality databases in Latin America. J. Econ. Inequality 13, 557-578 (2015)

Deaton, A.: Measuring poverty in a growing world (or measuring growth in a poor world). Rev. Econ. Stat. 87, 1-19 (2005)

Piketty, T.: On the long-run evolution of inheritance: France 1820-2050. Q. J. Econ. 126, 1071-1131 (2011)

Piketty, T.: Les hauts revenus en France au XXe siècle: Inegalités et redistributions 1901-1998. Paris: Grasset (2001)

Piketty, T., Saez, E.: Income inequality in the United States, 1913-1998. Q. J. Econ. 118, 1-39 (2003)

Ravallion, M.: Measuring aggregate welfare in developing countries: how well do national accounts and surveys agree? Rev. Econ. Stat. 87, 645-652 (2003)

Wolff, E.N., Zacharias, A.: Household wealth and the measurement of economic well-being in the United States. J. Econ. Inequality 7, 83-115 (2009) 